RU Когнитивно-семантический анализ структуры паремий с компонентом-зоонимом в татарском, русском и английском языках

Галимуллина Р. И.

\begin{abstract}
Аннотация. Цель исследования заключается в определении особенностей семантического структурирования татарских, русских и английских паремий. В ходе проведенного анализа выявляются универсальные и уникальные для рассматриваемых языков способы объективации символов животных и репрезентации компонентов-зоонимов в паремиях. Научная новизна исследования заключается в том, что в статье раскрываются семантические особенности пословиц и поговорок с компонентомзоонимом в татарском, русском и английском языках. В результате были выделены группы паремий и выявлены их различия и сходства. Впервые получены итоги сопоставительного анализа пословиц татарского, русского и английского языков с позиции когнитивной лингвистики, что позволило описать сходство и различия в пословичной концептуализации мира и в пословичном проявлении менталитета трех народов.
\end{abstract}

\title{
EN Cognitive-Semantic Analysis of Structure of Paroemias with Component-Zoonym in the Tatar, Russian and English Languages
}

\section{Galimullina R. I.}

\begin{abstract}
The paper aims to reveal the structural-semantic features of the Tatar, Russian and English paroemias. Relying on the conducted analysis, the author identifies universal and nationally specific means of the animalistic image objectification, describes functions of the zoonym component in paroemias. Scientific originality of the study involves a comprehensive semantic analysis of the Tatar, Russian and English proverbs and sayings with the zoonym component. The research findings are as follows: the author proposes a structural-semantic classification of the Tatar, Russian and English paroemias, identifies their universal and nationally specific features. The researcher for the first time provides a comparative analysis of the Tatar, Russian and English paroemias from the viewpoint of cognitive linguistics, which allows identifying similarities and differences between the Tatar, Russian and English paroemiological worldviews.
\end{abstract}

\section{Введение}

Актуальность данного исследования определяется тем, что зоонимы являются одной из универсальных языковых лексико-семантических групп любого языка. Изучение когнитивно-семантического потенциала паремий с компонентом-зоонимом направлено на выявление зооморфных образов, создаваемых в рассматриваемых паремиологических единицах в ситуациях общения.

Усиливает актуальность сопоставительный характер исследования. В настоящий момент прослеживается особый интерес к исследованию лексической системы татарского языка. Как отмечается в специальных исследованиях, описание лексической системы татарского языка является главным вопросом современных лексикологов.

Совпадение паремий разных народов по своему значению и форме притягивает исследовательский интерес паремиологов. Примечательно то обстоятельство, что сила особой роли паремий в передаче значимых для национальной культуры категорий находится в богатом смысловом запасе и объясняется рядом функционально-семантических характерных особенностей, которые указывают свойства паремий как языковых знаков особой природы. Отличительная особенность современных исследований заключается в наличии в паремиях внешних признаков, сочетающих структурные и смысловые признаки свободных, семантически связанных и формально значительных языковых единиц [11, с. 163].

Научная статья (original research article) । https://doi.org/10.30853/phil210388

(๔) 2021 Авторы. 000 Издательство «Грамота» (๔ 2021 The Authors. GRAMOTA Publishers). Открытый доступ предоставляется на условиях лицензии СС ВY 4.0 (open access article under the CС BY 4.0 license): https://creativecommons.org/licenses/by/4.0/ 
Достижение поставленной цели предполагает решение следующих задач:

1. Выявить в паремиологическом фонде татарского, русского и английского языков корпус паремий с компонентом-зоонимом.

2. Раскрыть когнитивно-семантический потенциал паремий с компонентом-зоонимом и провести каталогизацию анализируемой группы паремий в соответствии с их иллокутивной направленностью.

3. Изучить коммуникативные стратегии и тактики, реализуемые в паремиях с компонентом-зоонимом в татарском, русском и английском языках в сопоставляемых национальных паремиологических картинах мира с последующим выявлением общих и специфических черт.

В статье применяются следующие методы исследования: метод сплошной выборки речевого материала, описательный метод, сопоставительный анализ.

Результат состоит в том, что сопоставительный анализ паремий с компонентами-зоонимами в татарском, русском и английском языках выявил сходства и различия, были выделены семантические группы зоонимов. Единообразие языковой картины мира, универсальной для всех трех языков, устанавливается по итогам исследования когнитивных уровней значения и внутренней формы паремий.

Теоретической базой исследования послужили труды А. Дандес [13], А. Тейлор [20], В. Мидер [15], Н. Н. Семененко [11], посвященные описанию теоретических основ паремиологии в области исследования структурно-смысловой специфики паремий. Кроме того, учитывались работы Э. Н. Денмухаметовой [3], где все звери и животные, имеющие место в паремиях, являются аллегорическими образами и описываются с определенными качествами, свойственными человеку; Е. В. Ивановой [5], которая провела сопоставительный анализ пословиц и поговорок английского и русского языков с позиций когнитивной лингвистики.

Практическая значимость заключается в том, что результаты анализа могут использоваться при разработке спецкурсов и спецсеминаров по лингвистике, сопоставительной паремиологии, лингвокультурологии.

\section{Основная часть}

Эмпирическим материалом настоящего исследования стали татарские, русские и английские пословицы с компонентом-зоонимом, отобранные из сборников русских пословиц и поговорок И. М. Снегирева [12], В. П. Жукова [4], В. И. Даля [2] - были выделены 455 единиц, 342 единицы - из сборников английских пословиц и поговорок Дж. Спик [18], В. Мидер [15], 530 единиц - из сборника татарских пословиц и поговорок Н. Исанбета [6].

Выявленный в паремиологическом фонде татарского, русского и английского языков корпус паремий с компонентом-зоонимом позволил распределить татарские, русские и английские паремии на 4 лексикосемантические группы зоонимов и раскрыть их когнитивно-семантический потенциал.

1. Зоонимы, номинирующие птиц: тат. торна (журавль), бытбылдык (перепелка), песндк (синица), тургай (жаворонок), сандугач (соловей), карлыгач (ласточка), кугәрчен (голубь), сыерчык (скворец), карга (грач), саескан (сорока), ябалак (сова), тукран (дятел), тартар (коростель), күке (кукушка), каз (гусь), үрдәк (утка), әтәч (петух); рус. воробей, ворона, галка, голубь, гусь, грач, дятел, жаворонок, журавль, зяблик, индейка, кобчик, коршун, кукушка, курица, ласточка, лебедь, павлин, петух, попугай, синица, сова, сокол, соловей, сорока, тетерев, филин, цыплята, щеголь, чайка, ястреб; англ. сапагу (канарейка), сискоо (кукушка), chicken (цыпленок), сосk (nетух), crow (ворона), dove (голубь), duck (утка), eagle (орел), hawk (ястреб), jackdaw (галка), lark (жаворонок), kite (коршун), owl (сова), swan (лебедь), swallow (ласточка), turkey (индейка).

Выделение данной группы обусловлено тем, что во всех трех языках было обнаружено 864 (347 - в татарском, 300 - в русском, 217 - в английском языке) паремии с компонентом-зоонимом с зооморфом птиц.

Отметим, что в русских пословицах чаще всего используются прямые названия птиц (ворона, воробей, синица, журавль, орел, сорока, сокол), наряду с этим, в татарских и английских паремиологических единицах подавляющее большинство обобщенных названий птиц: кош - bird (nтица). A bird in the hand is worth two in the bush [15, p. 60]. / Птица в руках лучше двух, что в кустах; Кош оясыз булмый [6, б. 579]. / Не бывает птицы без гнезда; Видать птищу по полету [4, с. 68].

Рассмотрим зоонимы, номинирующие самых распространенных и часто встречающихся водоплавающих птиц, на трех примерах: рус. утка, тат. үрдәк, англ. duck; рус. гусь, тат. каз, англ. gооsе; рус. лебедь, тат. аккош, англ. swan.

Как с гуся вода, небывалые слова [Там же, с. 139]; С него всякая беда, как с гуся вода [2, с. 127]; Лейся беда, что с гуся вода [Там же]; Каз канатына су йокмас (букв. Через перья гуся вода не просочится) [6, б. 614].

Эквивалента с одинаковым значением в английском языке найдено не было. Также наблюдается употребление сразу двух компонентов-зоонимов в пословицах и поговорках в трех сопоставляемых языках: Сколько утка не бодрись, лебедем не быть [9, с. 67]; Полетели гуси за море, а прилетели тоже не лебеди [8, с. 173]; Белый лебедь серому гусю не товарищ [1, с. 20]; Лебедь летит к снегу, а гусь к дождю [11, с. 247] - народная примета о природных явлениях. All his geese are swans (букв. Все его гуси - лебеди) [15, р. 310]; Every mother thinks her own gosling a swan (букв. Всякая мать считает своего гусенка лебедем) [7, с. 47]; Берәүнең үрдәген ашасаң, казыңңның аягыннан тотып тор (букв. Если съешь чужую утку, держи крепче лапы своего гуся) [6, б. 613]; Каз каз белән, үрдәк үрдәк белән очар (букв. Гусь с гусем, утка с уткой полетит) [Там же, б. 614].

Рассмотрим паремии с компонентами-зоонимами, номинирующими перелетных птищ: рус. ласточка, тат. карлыгач, англ. swallow; рус. соловей, тат. сандугач, англ. nightingale; рус. грач, тат. кара карга, англ. rook. 
Уникальный пример использования наименования грач в пословице отмечен в сборнике русских пословиц и поговорок В. П. Аникина: Воробей сразу на взлет, а грачу разбег нужен [1, с. 49], - и в сборнике английских пословиц и поговорок В. Мидера: As black as a rook (букв. Черный как грач) [15, p. 66].

В сборнике татарских пословиц и поговорок Н. Исанбета найдены две паремии с данной лексемой: Кара карга гына картаймый (букв. Только грач не стареет) [6, б. 595]; Кара карганы сабынлап юсаң да агармас (букв. Грача хоть мылом отмывай) [Там же].

2. Зоонимы, номинирующие насекомых (118 - в татарском языке, 82 - в русском языке и 64 - в английском языке): рус. пчела, тат. бал корты, англ. beе; рус. комар, тат. черки, англ. gnat; рус. муха, тат. чебен, англ. fly; рус. муравей, тат. кырмыска, англ. ant.

Слово пчела в русских паремиях сопровождается глаголами активного действия «знает», «летит»: Пчела знает, где мед брать [9, с. 42]; Пчела далеко за каплей летит [Там же, с. 37].

Лексема bеe в английских паремиях («пчела») комбинируется с глаголами “gather” («собирать»), “suck” («втягивать, высасывать»): The bee sucks honey from the mire (букв. Пчела высасывает мед из трясины) [15, p. 25]; Bees gather honey from every flower (букв. Пчелы собирают мед с каждого цветка) [Ibidem]; Honey is sweet, but the bee stings (букв. Сладок мед, да пчелки жалятся) [8, с. 69].

В татарских паремиях лексема тат. бал корты, рус. пчела сочетается с глаголами «табарга» («найти»), «тутырырга» («наполнить»), «алырга» («взять»). Елан агу тапкан чәчкәдән бал корты бал табар (букв. В том цветке, где змея находит яд, пчела находит мед) [6, б. 556]; Бал кортын үтерсән, балны кайдан алырсың? (букв. Если пчелу убьешь, откуда мед возьмешь?) [Там же]; Жыен кырмыска чаян үтерә, жыен корт олы савыт бал тутыра (букв. Вместе муравьи скорпиона убьют, пчелы тарелку меда соберут) [Там же, б. 558].

На то, что пчела - полезное насекомое, указывает татарская паремия Кортның чагуы да файдага (букв. Укус пчелы и то к пользе) [Там же].

Слово комар в русских паремиях комбинируется с глаголами «пищит», «кусает». Комары кусают лишь до поры [12, с. 224]; Кусают и комары до поры [2, с. 215]; Сорока стрекочет, что князь на службу хочет, а комар пищит, хочет вытащить [12, с. 235].

В татарских паремиях наблюдается употребление глаголов «безелдәргә» («жужжать»), «черелдәргә» («визжать»): Черкинең талавыннан бигрәк безелдәве яман (букв. Жужжание комара хуже укуса) [6, б. 549]; Черки черелдәп жиңәр (букв. Комар победит визжанием) [Там же].

Нами зафиксированы эквиваленты паремий тат. чебен, рус. муха, англ. fly во всех трех сопоставляемых языках: В закрытый рот и муха не залетит [1, с. 35]; A shut mouth catches no flies (букв. Закрытый рот мух не ловит) [15, p. 286]; Йомган авызга чебен кермәс (букв. В закрытый рот муха не залетит) [6, 6. 548].

Значительный интерес вызван тем фактом, что в русском и английском языках выявлено только по одной паремии с лексемой муравей: Остерегайся врага, будь он хоть с муравья [9, с. 162]; Grain by grain and the ant fills his barn (букв. Зернышко по зернышку - и муравей наполнит свой амбар) [8, с. 272].

Примечательно то обстоятельство, что в татарском языке в отличие от русского и английского насчитывается наибольшее количество употреблений компонента-зоонима кырмыска (муравей). Данный зооним символизирует: 1) труд. Например: Кырмыска кечкенә дә таулар актара (букв. Хоть муравей и маленький, а горы переворачивает) [6, б. 554]; Кырмыска кышлык йорт салыр, коңгыз катып үләр (букв. Муравей себе на зиму дом построит, а жук от холода помрет) [Там же]; 2) силу и храбрость. Например: Кырмыска чикерткәне жиңдр (букв. Муравей и стрекозу победит) [Там же, б. 555]; Кырмыска үзеннән ничә кат авыр чыбыкка көче житә (букв. У муравья хватит сил поднять сучок в несколько раз больше своего веса) [Там же]; Кырмыска үлемндн курыкмас (букв. Муравей смерти не боится) [Там же]; Күмәк кырмыска дөяне үтерер (букв. Вместе муравьи и верблюда убьют) [Там же]; 3) способность, знание. Например: Кырмыска юлын белер (букв. Муравей дорогу знает) [Там же].

3. Зоонимы, номинирующие пресмыкающихся (55 - в татарском языке, 20 - в русском языке, 18 - в английском языке): рус. змея, тат. елан, англ. snake; рус. крокодил, англ. crocodile.

Мудрость, живучесть, бессмертие, целительные силы символизирует образ змеи. Слово змея сочетается с глаголом «ужалить» (“bite”, «чагарга») в русских, английских и татарских паремиях: Ужаленный змеей веревки боится [9, с. 217]; The man who has once been bitten by the snake fears every piece of rope [15, p. 28]; Елан чаккан адәм арканнан да куркыр (букв. Тот, кого ужалила змея, и веревки боится) [6, б. 576]; Еланга юлдаш булсаң, кулны чагар (букв. Будешь союзником змеи, ужалит руку) [Там же, б. 572].

Согласно проведенному исследованию, лексема крокодил в английских и русских паремиях сопровождается существительным «слеза» (“tear”): To shed crocodile tears (букв. Проливать крокодиловы слезы) [15, p. 183]. Женская беззлобность - крокодилова слеза [12, с. 166].

4. Зоонимы, номинирующие грызунов (10 - в татарском языке, 53 - в русском языке, 43 - в английском языке): рус. мышь, тат. тычкан, англ. тоuse; рус. бобр, тат. кондыз, англ. beaver; рус. белка, тат. тиен, англ. squirrel.

The mouse that has but one hole is quickly taken. Плоха та мышь, у которой только одна лазейка. Ср. Худа та мышь, которая одну лазею знает [9, с. 205]; The mountain has brought forth a mouse. Гора мышь родила [Там же, с. 113]. Ср. Мучилась гора родами, да родила мышь. Из пустяков да много шуму. Акыллы тычкан бер тишеккә ышанмас [6, б. 699] (букв. Умная мышь в одну лазейку не поверит).

Необычное сочетание глагола «убить» можно заметить в русских паремиях с лексемой бобр: Не убить бобра, не нажить (или: не видать) добра [2, с. 95]; Убил бобра, а нашел добра [Там же, с. 106]; На худом коне не убьешь бобра [12, с. 294]. 
В английских паремиях лексема beaver («бобер») несет положительный окрас, сочетаясь со словами “industrious, busy, work” («трудолюбивый, занятой, работать»). Например: To work like a beaver (букв. Работать как бобр) [15, p. 47]; As busy as a beaver (букв. Занятой как бобр) [Ibidem, p. 119].

Важно подчеркнуть тот факт, что зооморфный образ белки, представленный в татарских и русских пословицах и поговорках, не был замечен в английских паремиях: Арслан күләгәсендә тиен туеныр [6, б. 637] (букв. В тени льва кормится белка); Канат булмаса, тиен койрыгы белән оча [Там же, б. 662] (букв. Если нет крыльев, белка и на своем хвосте полетит); Белкуловить - ножки отбить [1, с. 20]; Бояться волка - бегать и от белки [Там же, с. 26].

\section{Заключение}

Все вышесказанное дает нам возможность сделать следующие выводы.

1. Анализ эмпирического материала в татарском, русском и английском языках позволил выделить различия, раскрывающие своеобразие национальной языковой картины мира. В фольклорных текстах паремиологические единицы охватывают все стороны общественной, хозяйственной, семейной жизни людей. При рассмотрении особенностей паремий важно учитывать, что умысел выражения у пословиц и поговорок имеет разного рода направления. Пословицы имеют структуру предложения, в то время как поговорки отображаются в форме словосочетаний.

2. Пословицы любого языка взаимосвязаны с типом образного мышления народа, отражают историю, культуру, традиции общества. Как показывает материал, в трех лингвокультурах можно указать сходства и различия в объективно-выразительном содержании пословиц и поговорок. Паремиологические единицы имеют большое значение в духовной жизни народа. В них запечатлен не только богатый жизненный опыт народа, но также ценнейшее лингвистическое наследие. Через пословицы и поговорки мы можем проникнуть в прошлое культуры и истории народа, изучить специфичность того или иного народа, что позволит нам использовать эти результаты в практических целях.

3. Анализ паремий с компонентами-зоонимами в трех языках (татарский, русский и английский языки) находит сходство на уровне семантики, и паремии объединены в фразеосемантические группы. Однако выразительность, которая характерна для разноструктурных языков, является особенной и выражает своеобразие мировидения народа.

Перспективы дальнейшего исследования проблемы мы видим в более детальном изучении внутренней когнитивной структуры татарских, русских и английских паремий. На наш взгляд, было бы интересно изучить паремиологические единицы в плане сравнения национальных паремиологических картин мира в различных лингвокультурах.

\section{Источники | References}

1. Аникин В. П. Русские пословицы и поговорки. М.: Худож. лит., 1988. 431 с.

2. Даль В. И. Пословицы русского народа: в 3-х т. М.: Русская книга, 1993. Т. 1. 640 с.

3. Денмухаметова Э. Н. Зоонимы и фитонимы в татарских паремиях // Альманах современной науки и образования. 2011. № 1 (44). С. 181-185.

4. Жуков В. П. Словарь русских пословиц и поговорок. Изд-е 4-е, испр. и доп. М.: Русс. яз., 1991. 534 с.

5. Иванова Е. В. Пословичная концептуализация мира: дисс. ... д. филол. н. СПб., 2003. 314 с.

6. Исәнбәт Н. Татар халык мәкальләре: мәкальләр жыелмасы: 3 томда. Казан: Татар. кит. нәшр., 1959. Т. 1. 780 б.

7. Махмутов Х. Ш. Татарское народное творчество: в 15-ти т. Казань: Татар. кн. изд-во, 2017. Т. 1. 366 с.

8. Митина И. Е. Английские пословицы и поговорки и их русские аналоги. СПб.: КАРО, 2009. 336 с.

9. Мюррей Ю. В. Русские пословицы, поговорки и фразеологизмы и их английские аналоги. М. - СПб.: АСТ; Сова, 2008. 384 с.

10. Рыбникова М. А. Русские пословицы и поговорки. М.: Изд-во Академии наук СССР, 1961. 229 с.

11. Семененко Н. Н. Русские паремии: функции, семантика, прагматика. Старый Оскол: РОСА, 2011. 355 с.

12. Снегирев И. М. Русские народные пословицы и притчи. М.: Эксмо, 2010. 576 с.

13. Dundes A. Folk Ideas as Units of Worldview // Toward New Perspectives in Folklore / ed. by A. Paredes, R. Bauman. Austin - L. - Texas: University of Texas Press, 1972. P. 94-103.

14. Kamaeva R. B. National cultural specifics of representing dialecticisms in the fiction work translation // Life Science Journal. 2014. Vol. 11. № 10. P. 653-656.

15. Mieder W., Bryan G. B. Anglo-American Proverbs and Proverbial Phrases Found in Literary Sources of the Nineteenth and Twentieth Centuries. N. Y.: Peter Lang Publishing, 2005. 870 p.

16. Schank R. C., Abelson R. P. Scripts, plans, goals, and understanding: An inquiry into human knowledge structures. Hillsdale - N. Y., 1977. 248 p.

17. Searle J. R. Speech acts: An essay in the philosophy of language. L.: Cambridge University Press, 1969. 261 p.

18. Speake J. Oxford Dictionary of Proverbs. N. Y.: Oxford University Press, 2008. 388 p.

19. Stevenson B. The Home Book of Proverbs, Maxims and Familiar Phrases. N. Y.: The MacMillan Company, 1956. 2750 p.

20. Taylor A. Selected writings on proverbs / ed. by W. Mieder. Helsinki, 1975. 239 p.

21. The Concise Oxford Dictionary of Proverbs. Oxford - N. Y.: Oxford University Press, 1998. 333 p. 


\section{Информация об авторах | Author information}

\section{RU Галимуллина Рузиля Ирековна ${ }^{1}$}

${ }^{1}$ Казанский (Приволжский) федеральный университет

\section{EN Galimullina Ruzilya Irekovna ${ }^{1}$}

${ }^{1}$ Kazan Federal University

${ }^{1}$ ruzilya.vahitova@mail.ru

\section{Информация о статье | About this article}

Дата поступления рукописи (received): 25.04.2021; опубликовано (published): 15.09.2021.

Ключевые слова (keywords): паремия; компонент; семантика; зооним; пословица; paroemia; component; semantics; zoonym; proverb. 